\title{
Application Of The Miranda Principle In Terms Of Presenting The Legal Counsel For Criminal Suspects In Indonesia
}

\author{
Moch Faisal Kafrawi \\ Faculty of Law, Hasanuddin University \\ Jl. Perintis Kemerdekaan KM. 10, Tamalanrea, Makassar, 90245, Indonesia. \\ Tel/Fax.: +62+62-411-585035 E-mail:Ichalfay33@gmail.com
}

\begin{abstract}
This study was to determine how the application Miranda Principle in Indonesian legislation system and to find out how its implementation by law enforcement officials. Research conducted qualitatively by focus on a library study with approach of primary legal materials and secondary law. The results showed that in Indonesia, Miranda Principle set in several chapters: chapters 54, 55, 56 paragraph (1) and Article 114 Criminal Procedure Code. But in practice in some cases is still less than the maximum, especially in terms of presenting legal counsel for justice seekers who can not afford in this case the suspect / defendant.
\end{abstract}

Keywords: Principle Miranda; Miranda Rule; Miranda Warning; Legal Counsel; Criminal Procedure Code; Human Rights

\section{INTRODUCTION}

Indonesia is the country's constitutional normatively law. As a country that emphasizes the positive law as a rule of the game in the life of the nation but also to make the law as commander, then it contains far-reaching consequences in the midst of the community that everything related to the behavior and livelihood of the public purposes should be regulated by law.

In the running life of the state of law, law enforcement is a very important pillar in realizing the promises of law become a reality. The term "law enforcement" is very broad, and therefore includes those who are directly involved in the field of Article 1, paragraph 3 of the Constitution of the Republic of Indonesia Year 1945, but referred enforcement of law enforcement in this article, namely in the areas of police, prosecutors, the judiciary. Police, prosecutors, and judges who are given authority and facilities to perform its function in ensuring security, order and justice in the country, to serve and protect the public. However, amid the authority of the legal apparatus that they are not able to 
perform excellent in serving the community, especially in implementing the principles of Miranda (Miranda Principle) less performing well.

Principles Miranda rule, in the country of Indonesia has been accommodated into the Criminal Code, namely the right to obtain / contact legal counsel / advocate, and if they could not then be entitled to provide legal counsel/ advocate. The right to obtain legal assistance accommodated in Article 54, Article 55 and Article 114 Criminal Procedure Code. Whereas if you can not afford, the suspect has the right to legal counsel provided by the authorities concerned or the investigator (Article 56 paragraph 1 of the Criminal Code). ${ }^{1}$

Miranda includes a First Principle, Miranda Rule are the rights of suspects that includes the right not to answer the questions officials concerned in the criminal justice process and the right to be accompanied or represented legal counsel since the investigation process up to and/or in all levels of the judicature process And Both Miranda Warning is more emphasis on the obligations of officials concerned to remind and/or appoint or provide legal

\footnotetext{
${ }^{1}$ http://www.negarahukum.com/hukum/mir anda-rule.html, diakses 15 Maret 2016
}

counsel for the suspect or defendant in any judicature process.

In the process of investigation related to the protection of the rights of the suspect, a suspect obtain legal protection according to the terms set in the Criminal Code, such as:

1. The right to have legal representation since the arrest.

2. The right to contact legal counsel.

3. Implementation of the principle of "presumption guilty".

In addition to the rights of suspects in the investigation of the above, the following are the rights of suspects / defendants stipulated in the Criminal Code:

1. The right to investigation and speedy trial. This guarantee to keep the possibility of dangling fate of a person in custody and the lack of legal certainty, ill-treatment and unnatural state apparatus. This arrangement is also to ensure justice is done with a simple, fast and inexpensive (speedy trial).

2. The right to freely provide information to the investigator or a judge. Remarks that are free from a suspect or defendant greatly affect the decisions made by the judge in a case that happened to him. Therefore, a suspect or defendant 
must be guaranteed free of pressure, coercion, torture and fear of various parties in the examination process.

3. The right to legal counsel at every level of examination.

4. The right granted by the State's legal counsel free of charge to assist the suspect or the accused at every level of examination.

5. The right to communicate with legal counsel

6. The right to bring witnesses / expert

7. The right to redress and rehabilitation. The defendant is entitled to sue for damages since arrested, detained, prosecuted or subjected to other measures, without any reason based on law or in error about the person or legal diterapkan.

\section{METHODS}

This paper uses normative legal approach to assessing the application of Principle Miranda in the Indonesian criminal justice system. This paper uses primary and secondary legal materials. Primary legal materials obtained from legislation that is relevant to the issue of research, and secondary material obtained from a number of books, court decisions, internet resources and other sources relevant to research issues.

\section{ANALYSIS AND DISCUSSION \\ Provision of Legal Assistance for Crime Actors in Indonesia.}

In Indonesia, Miranda Principle set in several chapters: chapters 54, 55, 56 paragraph (1) and Article 114 Criminal Procedure Code. Miranda Rule principle contained in article 56 paragraph

Criminal Procedure Code, which reads:

"In the case of a suspect or a defendant suspected of or charged with a criminal offense punishable by the death penalty or a penalty of fifteen years or more or for those who can not afford is punishable by five years or more who do not have your own legal counsel, officials concerned on all levels of examination in the proceedings shall appoint counsel for them ".

From the wording of article above is clear that a suspect / defendant who commits an offense is punishable by five years or more are entitled to be presented a lawyer if they are not able to bring a lawyer for himself. The presence of a lawyer is needed to guarantee the examination fair and humane towards self suspect / defendant, because the presence of Counsel to assist, defend the legal rights for the suspect or the accused since of the investigation until the hearing is intended to play a role in the control, the investigators, prosecutors and judges so 
that the process of examination of the suspect/defendant spared from torture, coercion and cruelty and examinations that are not fair in hearing conducted law enforcement in the judicial process that resulted in the violation of the Criminal Code itself and cause the results of the investigation can be declared void by law and violation of human rights.

The provisions in Article 56 paragraph (1) Criminal Procedure Code in the light of the strict approach to law or legal formalities contain some aspects of legal issues, among others:

1. Contains the value aspect of Human Rights where each suspect/accused has the right in legal counsel in order damping level of scrutiny in the judicial process, it is in line with the Universal Declaration of Human Rights which states the presence of the Legal Counsel assisting the suspect/defendant is an inherent value in themselves human. Thus ignoring it is contrary to human rights values;

2. The fulfillment of these rights in the criminal justice process all levels of inspection, the duty of officials concerned, if the crime charged/indicted punishable by death/15; or for those who can not afford is punishable by five years or more, who do not have lawyers, the officials concerned in all levels of examination shall appoint counsel for them. And it is imperative that, if neglected, lead to the results of the assessment and investigation invalid or null and void;

Article 56 paragraph (1) Criminal Code as a provision of value of human rights has been appointed as one of the reference Miranda Rule. If the examination of the investigation, prosecution or trial of the suspect/defendant is not legal counsel then in accordance with the Miranda rule, the examination invalid/void (null and void).

Advocates/counsel shows by the authorities concerned to assist suspects/defendants who can not afford, as described in point 2 (two) above, provide assistance free of charge. It is clearly stipulated in the Criminal Code which reads:

"Every lawyer appointed to act as intended in paragraph (1), provide assistance free of charge".

Regarding the provision of legal aid free of charge to those who can not afford the real is the duty of the Advocate, it is stipulated in Article 22 of Law No. 18 of 2003 advocates 
that states: Article 56 paragraph (2) of the Law of Criminal Procedure.

1. Advocates shall provide legal assistance free of charge for justice seekers who can not afford.

2. The provisions regarding the requirements and procedures for the provision of legal aid free of charge referred to in paragraph (1), shall be further regulated by Government Regulation.

And the Code of Ethics of Indonesian Advocates (KEAI) states that:

"Advocates in the care of the case free of charge should give the same attention to the case for which he received fees."

There is also a condition of the hearing aid by advocates for free are: 13a. Apply in writing which contains at least identity And Procedures for Legal Aid and Legal Aid Fund distribution.

Applicant Legal Aid and a brief description of the subject being applied for Legal Aid;

a. Hand over documents relating to the Case; and

b. Attaching this letter from the village chief, the village head, or the official level in residence Applicant Legal Aid.
Applicant legal aid to file an application in writing to the Advocate / giver legal aid or through organizations Advocate or Legal Aid. Where the applicant is not able to submit a written request may be submitted verbally, verbally request is then poured in writing and signed by the applicant and the advocates or the clerk at the lawyers' organization or Legal Aid assigned to it.

Besides the legal aid budget funds from the state budget, the budget, grants or donations and other funding sources are legitimate and not mengikat.15 And also to the procedure of budget proposals by way of legal aid providers to submit a plan to the legal aid budget minister fiscal year before the fiscal year relief operation hukum.16 Miranda Principle Application process Criminal Justice in Indonesia. A concrete example of respect for the Miranda Rule, Yogyakarta police investigator in particularly the drugs have partnered with LHS \& Partners Law Office inYogyakarta, where the investigator Police Narcotics Section DIY whenever there are arrest criminal suspects drugs then they perform their obligations to appoint counsel for a suspect, as in the Criminal Procedure Code specifically mandated by Article 56 paragraph (1). The technical is that every time they make an 
arrest of suspects in drug cases, prior to examination of the suspect, they immediately ask arrival advocate in the office LHS \& Partners, by way of the investigator contacted the lawyers concerned accompanied by issuing a letter of request and appointment formally to the office LHS \& Partners. While LHS \& Partners Law Office issued an assignment to advocate or a particular law in LHS \& Partners Law Office to accompany the suspects free or free of charge in accordance with article 22 of Law No. 8 Year 2003 on Advocate.

Aside from the investigating authorities, respect for the Miranda Rule has also been realized in the verdict. For example, the decision of Supreme Court of Court of the Republic of Indonesia Number 1565k / Pid / 1991, dated 16 September 1993 which states "if the terms of the request and / or the right of the suspect / defendant is not being met as well as investigator, prosecutor charges against the defendant declared unacceptable" .18 Rights Violations shape suspect / defendant.

According to Drs. M Sofyan Lubis, SH in his book "Principles" Miranda Rule "Rights of Suspects Before the examination", the violations that often occur in the application of Article 56 paragraph (1) and (2) are as follows:

1. Police / Investigation Agencies

a) Many police officers arrested the suspect and then the suspect at the scene immediately questioned / interrogated, without prior reminder of his rights as a suspect (Miranda Warning);

b) With arguments of the suspect does not have the money and the rights of suspects, many police officers suggested that the suspect does not have to use legal counsel, and the suspect is conditioned in such a way to make him an affidavit is not willing to legal counsel, and not a few of the investigators considered that the presence of statements of self suspects who are not willing to legal counsel is a human right, so investigators did not feel the need any more to fulfill obligation to appoint counsel for the accused as required by Article 56 paragraph (1) Criminal Procedure Code.

c) With the proposition to expedite the investigation process, many police officers working to make 
each of the accused should not use legal counsel or advocate;

d) With no arguments of counsel who want assigned free of charge to accompany the suspects, many investigators ignores its obligations as mandated in Article 56 paragraph (1) Criminal Procedure Code;

e) Absence of Police Institutions budget intended to provide legal counsel for the accused.

2. Level of Attorney

a. The proposition is not done examination again, so many unscrupulous prosecutors/public prosecutors do not need to appoint counsel to assist the suspect /defendant;

b. With the argument of the existing waiver is not willing to legal counsel made at the level of investigation, the provisions of Article 56 paragraph considered to have been met;

c. With a proposition no one wants appointed legal counsel free of charge to accompany the suspects, many attorneys/public prosecutor or the District Attorney ignores its obligations as mandated in Article
56 paragraph (1) Criminal

Procedure Code;

d. Absence of the institutional budget prosecutor to provide legal counsel for the accused.

3. Level Court of Justice

a. The proposition still going controversy regarding the application of Article 56 paragraph (1) Criminal Code, the judge is free to follow any opinion;

b. With the argument of the legislation has not been set explicitly, then the judge is authorized to decide in accordance with his conscience;

c. With the argument of public interest, the rights of the accused can be ruled out;

d. There is no special budget of Institutions court concerned to provide legal counsel for the accused;

e. Judges reserve the right to not be blamed or sued for negligence in checking and deciding a case. Actually, from all of the above offenses, particularly on judicial assistance free of only for justice seekers who can not afford, it has been described in Article 22 of 
Law No. 18 Year 2003 is lawyer shall provide legal assistance free of charge for justice seekers who can not afford. Also in PP 83 of 2008 has set the terms and procedures for granting legal aid free of charge and also PP 42 Year 2013 has set the terms and procedures for granting legal aid and legal assistance fund distribution. Therefore, if this is the reason it needs to be asked again about the rule of law that does not comply with the rules of the existing legislation.

Likewise reason that judges can not be blamed for negligence in examining and deciding a case it is true, but in this case if the negligence of the judge in deciding a case is not knowing that the defendant was not accompanied by a lawyer for the defendant's inability to bring legal counsel, not because of unwillingness of the accused to obtain legal aid. Perhaps this is probably questionable back "whether it is negligence and not a deliberate"? And also the reason expedite the investigation process, according to the author if this proposition is used so as not as lawyer for the suspect/defendant, of course, it is a big mistake, because it will bring negative aspects of the rule of law itself, namely the cancellation of the rule of law itself if known, was carried out with the deliberate violation of the law enforcement officers in the delivery of the rights of suspects.

All of the violations above of course is a black mark in law enforcement in Indonesia, and it is not possible according to the author, the same thing will decline in the next generation of law enforcement. If this is not done it is not possible rights of the accused will be lost and cause a violation of the rules and human rights committed by law enforcement officers themselves.

\section{CLOSING}

Miranda Principle covers, First, Miranda Rule that the constitutional rights of suspects that includes the right not to answer the questions officials concerned in the criminal justice process and the right to be accompanied or represented legal counsel since the investigation process up to and/or in all levels of the judicial process. And second, Miranda Warning is more emphasis on the obligations of officials concerned to remind and/or appoint or provide legal counsel for suspect or defendant in any court proceedings.

Miranda principle adopted in several chapters in the Book of the Law of 
Criminal Law Indonesia. Therefore, the protection of the rights of the suspect (Miranda Rule) is the imperative nature/necessity to be implemented, so that if it is ignored result for any reason can result in the cancellation of the enforcement of criminal law itself. Besides violation of the Miranda Rule is a violation of Human Rights (HAM) due to the universal declaration of human rights which confirms the presence of the Legal Counsel assisting the suspect / defendant is the value inherent in human beings, thus ignoring it is contrary to human rights values.

\section{BIBLIOGRAPHY}

Bambang Tri Bawono. (2011). Overview Juridical Rights Of The Suspect In The Preliminary Examination. Jurnal Hukum 26: (2)

2008.
Pelanggaran Terhadap Prinsip
"Miranda Rule" Dalam Praktek
Peradilan Pidana di Indonesia.
http://www.lawskripsi.com/index.ph
p? Option = Com_content \& view =
articl e \& id = 95 \& Itemid = 95.
Access on 10 November 2015.

LBH Jakarta, Jaminan Perlindungan Hak Tersangka dan Terdakwa Dalam KUHP dan KUHAP, kuhap.or.id/data/wp- content / uploads / 2013/10 / rights of suspects-defendant-by-LBH-

Jakarta.pdf. Access on December 10, 2015 from 23.00.

Soerjono Soekanto, 2012, Factors Affecting Law Enforcement, Prints 11th, Jakarta: PT RajaGrafindo Persada.

Sofyan Lubis. 2010. Principles "Miranda Rule" Rights of Suspects Before Examination lest you become a victim of justice. Yogyakarta: Pustaka Yustisia. University of North Sumatra, http://repository.usu.ac.id/bitstream/ 123456789/36856/3/ Chapter\% 20I.pd f. Access dated December 17, 2015 16:15 AM. 